\section{ENTRE, SENTE-SE À MESA E PARTICIPE DAS IGUARIAS}

Lívia de Oliveira

MONTANARI, Massimo. Histórias da mesa. São Paulo: Estação Liberdade, 2016. 230p. ISBN: 978-85-7448-270-5.

"A comida alimenta e a bebida mata a sede, mas comidas bebidas são muitas outras coisas também. São formas de expressar pertenças e identidades, relações." Massimo Montanari (2016, p. 11)

Vamos adentrar em histórias rocambolescas, fantásticas e saborosas. Vamos nos deixar ser levados pelos escritos, pelos contos orais, pelas descrições de lautos banquetes. Tudo isso e muito mais estão contidos nestas "Histórias da Mesa", reveladas por Massimo Montanari. Este exímio historiador medieval nos brinda em seu apaixonante livro, com sua imaginação exuberante de "épocas diferentes, mas não muito distantes, dos séculos centrais da Idade Média até o Renascimento, com alguns prolongamentos no século XVII" (p. 12). Por sinal, está traduzido, com cuidado e primor, por Federico Carotti.

Alguns personagens são reais (Carlos V, Carlos Magno, Dante, rainha Cristina), outros fictícios, porém todos glutões, amantes da boa comida. Desfilam-se pelas crônicas: reis, rainhas, imperadores, duques, papas, bispos, monges, cavaleiros, damas, mestres, santos, músicos, plebeus, padeiros, confeiteiros, cozinheiros e serviçais diversos. Uns são italianos, alemães, outros franceses, sarracenos. Tudo o que os une é a mesa. Ora, é um casamento, um banquete, ora, festas comemorativas, com a presença do anfitrião, de um séquito com convidados e do sem número de pessoas subalternas para servir e orientar a comilança. São trocadas as toalhas e os guardanapos até três vezes.

Os serviços eram de aparador e ou de cozinha. O primeiro consistia em doces confeitados, frutas frescas e cristalizadas, verduras e em geral eram apresentados frios.

1 Professora Emérita da Universidade Estadual "Júlio Mesquita Filho" (UNESP). liviadeoliveira@yahoo.com.br. $\gtrsim$ Rua 1, n.705, apto.43, Rio Claro, SP. 13500-402.

Geograficidade | v.8, Número 2, Inverno 2018 ISSN 2238-0205

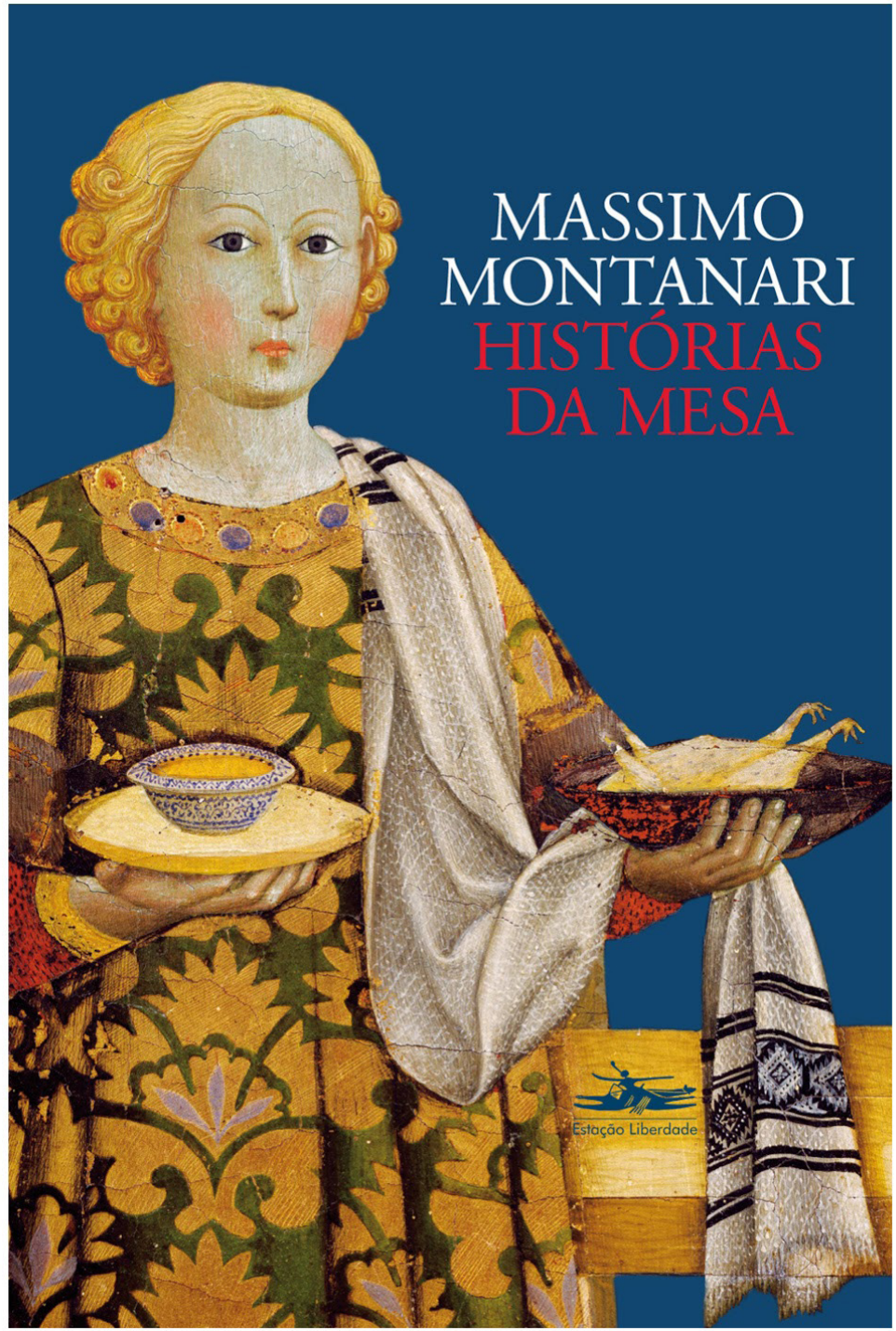


O segundo, vinham diretamente, quentes e borbulhantes, da cozinha. Destacavam-se os grandes mestres de cozinha, como Bartolomeo Scappi, Bartolomeo Stefani, mestre Martino, Messi Sbugo e outros mais.

O banquete oferecido a Carlos V, quando de visita ao papa Paulo III, em Roma, foi algo que marcou a culinária italiana da época (p. 175). Foram servidos 150 pratos diferentes, composto de doze serviços, cinco de aparador e sete de cozinha. Só no primeiro serviço foram oferecidos oito pratos de aparador e treze de cozinha. As carnes consistiam de porco, leitão, vitela, cabrito, cavalo, cordeiro; as de caça eram de javali, veado, lebre; as de aves incluíam pombo, faisão, cisne, pavão, capão, galeto, galinha, pato, marreco; os peixes e os crustáceos eram variados. Legumes, hortaliças, verduras e cogumelos eram guarnições, que complementavam os pratos. As frutas frescas ou cristalizadas embelezavam e adoçavam as comidas. A ordem de apresentação era intercalar doces com salgados. Os modos de preparo eram de centenas maneiras. Desde o simples e o múltiplo cozimento, assado, grelhado, frito, até as sopas, caldos finos e os molhos. Podiam ser à florentina, à siciliana, à milanesa, à romana, à veneta, etc. etc. $O$ estilo podia ser "adriático" ou a "tirreno", "não só no sentido vertical, de sul a norte, mas também horizontal entre leste e oeste, de um lado e do outros dos Apeninos" (p. 180). Aliás, "os senhores de maior importância comiam em separados de seus convidados" (p. 161).

As frutas servidas no aparador, em geral, eram uvas, peras, pêssegos, marmelos, bergamotas, morangos, ameixas, limões, laranjas, figos, damascos, maçãs. E o que relatar sobre as tábuas de queijos e as cartas de vinhos? Era uma profusão e opulência, sem fim, de vinhos: tintos, brancos, rosados, adamados, frisantes. Os queijos de toda a península itálica: parmesão, pecorino, mascarpone, grana padano, provolone, mozarela. A arte da mesa consistia em transformar açúcar em decorações artísticas. Também, se seguiam de apresentações musicais, acompanhadas de alaúde, viola, flauta ou trombone.

Montanari, em sua alma, transforma histórica e geograficamente, a cozinha em arte, em prazer, em sabor. 